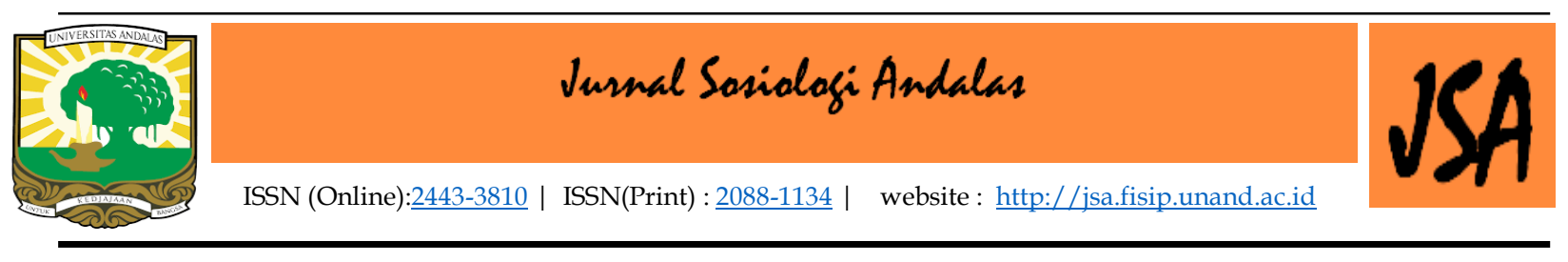

\title{
Pola Interaksi Anak dengan Ayah Tiri dalam Keluarga Remarriage
}

\author{
Indah Sari Rahmaini \\ Fakultas Ilmu Sosial dan Ilmu Poltik, Universitas Gadjah Mada, Yogyakarta \\ Email: indah.rahmaini@gmail.com
}

\begin{abstract}
Abstrak: Children are an asset of the nation that must be guarded and protected. But the child in the family remarriage in particular relationship with the father is less fulfilled its rights that can be seen from the interaction that occurred. The study aimed to describe the pattern of interaction of children with stepfathers in the family remarriage. This study was conducted with qualitative approach and informants were chosen by purposive technique as well as in data collection using observation technique and in-depth interview. The theory used is the symbolic interactionism of Herbert Blumer. The results of this study was the social setting of the interaction of children with stepfathers was the dinner together, the accompaniment of children learning, watching TV together, the transfer of children to school, recreation, and visiting the stepfather's family. The social context of child interaction with stepfathers was the interaction as a means of communication, interaction as the purpose of communication, and the involvement of the mother in the interaction. For interaction as a means of communication was giving advice to children and giving rewards to children. The interaction as the purpose of communication was farewell and shake before traveling and direct the orientation of the child forward.
\end{abstract}

Keywords: Children, Remarriage, Symbolic Interactionism

\section{A. PENDAHULUAN}

Anak merupakan aset bangsa yang harus dijaga dan dilindungi. Anak memerlukan segala hak-haknya untuk tumbuh dan berkembang serta mendapatkan perlindungan dari segala bentuk kekerasan, eksploitasi dan diskriminasi. Anak adalah tunas, potensi dan generasi muda penerus cita-cita perjuangan bangsa. Anak memiliki peran strategis yang mempunyai ciri dan sifat khusus untuk menjamin kelangsungan eksistensi bangsa dan negara pada masa depan, sehingga setiap masyarakat berkewajiban untuk memberikan perlindungan dalam rangka untuk kepentingan terbaik bagi anak (Rulli, 2016:1).

Negara Republik Indonesia telah meratifikasi Konvensi Hak Anak melalui Keputusan Presiden Nomor 36 Tahun 1990. Dalam Konvensi Hak Anak atau disingkat dengan KHA menjadi dasar bahwa anak memiliki hak-hak pokok yang harus diakui oleh berbagai pihak. Ada 4 hak pokok anak yang wajib dipenuhi adalah diantaranya: hak hidup; hak tumbuh kembang; hak perlindungan; dan hak partisipasi yang merupakan bagian dari Hak Asasi Manusia (HAM).

Di Dalam perspektif sosiologi, terdapat kesinambungan antara hak satu dengan hak yang lainnya. Hak partisipasi tidak akan bisa didapatkan tanpa adanya hak hidup. Begitupun dengan hak tumbuh kembang tidak akan didapatkan tanpa hak perlindungan. Tidak akan mungkin seorang anak bisa tumbuh kembang tanpa 
dilindungi. Jadi, perlindungan anak yang dilakukan menunjukkan bahwa harus terpenuhinya hak-hak pokok anak dalam suatu masyarakat secara menyeluruh.

Keluarga merupakan unit sosial terkecil yang memberikan pondasi primer bagi perkembangan anak. Sedang lingkungan sekitar dan sekolah ikut memberikan nuansa pada perkembangan anak. Karena itu, baik-buruknya struktur keluarga dan masyarakat sekitar memberikan pengaruh baik atau buruknya pertumbuhan kepribadian anak (Kartono, 57: 2013). Anak membutuhkan perlindungan dari berbagai pihak yang terlibat di dalam lingkungan sosialnya. Perlindungan tidak hanya wajib diberikan oleh negara, masyarakat, dan sekolah saja, namun wajib dilakukan oleh keluarga sebagai agen sosialisasi primer anak.

Keluarga memiliki fungsi-fungsi yang didapatkan anak dalam mempersiapkan tugas-tugas kehidupannya serta dapat memenuhi kebutuhannya untuk siap hidup bermasyarakat. Fungsi tersebut antara lain: fungsi sosialisasi, fungsi afeksi, fungsi pendidikan, dan lain sebagainya.

Penyaluran fungsi dari keluarga juga merupakan konteks belajar yang utama bagi suatu perilaku, pikiran, dan perasaan dari seorang individu. Orang tua merupakan "guru" yang utama, karena orang tua menginterpretasikan dunia dan masyarakat bagi anak-anak.

Namun pada kenyataannya, tidak semua anak terpenuhi haknya, khususnya dalam lembaga keluarga. Hal ini disebabkan oleh keluarga yang serta merta mengalami hubungan yang harmonis mulai dari perdebatan, pertengkaran, bahkan perceraian. Proses berakhirnya suatu pernikahan dengan berbagai macam akibat yang ditimbulkannya merupakan mimpi buruk bagi anak. Sulit bagi anak untuk mendapat hak pokoknya jika orangtuanya memutuskan untuk bercerai (Fachrina, 2009:2).

Sebagai salah satu upaya pengganti pemenuhan hak anak dalam sebuah keluarga yang bercerai, hal konvensional yang dilakukan adalah menikah kembali atau remarriage. Ada beberapa alasan remarriage dilakukan oleh laki-laki maupun perempuan. Alasan yang pertama adalah laki-laki dan perempuan yang memilih untuk menjadi single parent akan mengalami dampak orang tua akan berhutang kepada anak atas pertumbuhannya (Gierveld, 2004: 236).

Ada banyak permasalahan yang terjadi di antara hubungan anak dengan ayah tiri dari dua sisi. Pada sisi anak, menurut Warshak (2010 : 249), anak yang hidup di lingkungan orangtua tiri atau keluarga tiri mengalami rasa kecewa, cemburu, narsis, dan kompetitif. Ia merasa kecewa dengan orang tua tirinya. Kekecewaan tersebut dikontribusikan oleh salah satu orang tua yang tidak mendapatkan hak asuh. Anak terasing dari orang tua tirinya berkat orang tua kandung yang tidak memiliki hak asuh walaupun orangtua tiri sudah berbuat banyak untuk kebaikan si anak. Teralienasinya anak atas orangtua tirinya juga berhubungan dengan besar kecilnya kuantitas maupun kualitas interaksi si anak dengan orangtua tirinya.

Didukung oleh Rossnanda (2010:8), adaptasi dalam keluarga remarriage didasari atas beberapa ruang lingkup penyesuaian diri baik suami, istri, anak-anak antara lain karakter, sikap, kebiasaan, pembagian peran, dan kondisi keluarga yang membawa atau tidak anak-anak dalam keluarga remarriage. Konflik yang ditimbulkan dalam keluarga remarriage adalah penolakan berlebihan atas keluarga tiri anak. Menurut Mufidatu (2015:14) kemudian mempertegas bahwa anak belum 
sepenuhnya dapat terbuka dengan orang tua tiri. Respon seorang anak terhadap penerimaan orang tua baru di dalam keluarganya berbeda-beda.

Adapun pada sisi ayah tiri, banyak kita temukan ayah tiri yang melakukan kekerasan terhadap anak tiri. Baik kekerasan fisik, verbal, maupun kekerasan seksual. Hal ini sudah menjadi rahasia umum baik dari media maupun masyarakat luas. Kasus tersebut juga seakan terus mengalir dan menjadikan anak sebagai korban sehingga melanggar undang-undang perlindungan anak. Bahkan kasus ayah tiri yang melakukan kekerasan terhadap anak sulit diketahui masyarakat karena keluarga kian menutupi dengan alasan aib bagi keluarga itu sendiri.

Dari data dan fakta yang telah diuraikan, penelitian yang dilakukan adalah menganalisis permasalahan anak dan ayah tiri dari sisi anak berdasarkan pola interaksi anak dengan ayah tiri. Nantinya, pola interaksi tersebut memberikan kita jawaban mengapa permasalahan dari sisi anak seperti yang diterangkan pada paragraf sebelumnya bisa terjadi.

Penelitian ini penting dilakukan berkaca atas penelitian sebelumnya yang membahas masalah remarriage menggunakan perspektif keluarga, tapi kurang melihat bagaimana pengalaman anak sebagai bagian aktif dari sebuah keluarga remarriage serta dalam memandang ayah tirinya. Penelitian sebelumnya lebih sering menginterpretasi permasalahan pada aspek struktur dan menjadikan anak sebagai objek. Padahal menurut perspektif anak, penting rasanya untuk menjadikan anak sebagai subyek penelitian bukan hanya menjadi pelengkap dari penelitian mengenai keluarga remarriage. Pentingnya penelitian ini dilakukan juga didukung oleh tingginya angka remarriage di Kelurahan Kapalo Koto sebagaimana yang terlihat pada tabel berikut:

Tabel 1. Data Remarriage Kecamatan Pauh

\begin{tabular}{cccccc}
\hline No & Tahun & D-J & D-P & P-J & Jumlah \\
\hline 1. & 2014 & 19 & 1 & 4 & 25 \\
2. & 2015 & 25 & 0 & 1 & 26 \\
3. & 2016 & 15 & 0 & 3 & 18 \\
4. & 2017 & 19 & 1 & 2 & 22 \\
\hline
\end{tabular}

Keterangan:
D-J : Duda Janda
D-P $:$ Duda Perawan
P-J $\quad$ : Perjaka Janda

Jika kita perhatikan dari penelitian sebelumnya, anak tidaklah menjadi aktor yang memiliki peranan penting dalam suatu kajian penelitian. Anak hanya mendapat tempat sebagai poin tambahan. Tidak banyak penelitian yang mengkhususkan anak sebagai kajian khusus dalam sebuah disiplin ilmu. Jika pun ada, mungkin tidak untuk disiplin ilmu sosiologi. Masalah anak banyak dibahas oleh disiplin ilmu psikologi dan hukum saja. Padahal, sosiologi memiliki perspektif 
anak yang bisa menjadikan anak sebagai individu mandiri serta mampu mengkonstruksi realitas sosial pada masyarakat luas. Perbedaan dari penelitian yang dilakukan ini adalah penulis mencoba untuk berani memakai perspektif anak. Sumber informasi dari anak baik itu kata-kata, pendapat, dan argumentasinya akan diinterpretasi menjadi data yang ilmiah

Anak merupakan individu yang wajib untuk dilindungi oleh lingkungan sosial masyarakat, khususnya keluarga. Tidak diberikannya fasilitas maupun agen sosialisasi yang baik bagi anak artinya mengganggu akses anak terhadap haknya. Salah satunya adalah keluarga remarriage. Datangnya ayah tiri sebagai peran baru dalam kehidupan anak menjadikan anak harus melakukan penyesuaian terlebih dahulu, khususnya bagaimana anak berinteraksi dengan ayah tiri. Apalagi, kita tidak dapat mengetahui berapa anak yang terlibat setiap tahun dalam berbagai bentuk perpecahan keluarga, karena kita tidak tau berapa kasus yang terjadi. Hal ini sangat berkaitan erat dengan munculnya peran baru dalam diri anak. Jika saja terjadi kegagalan peran didalam rumah, maka akibatnya akan membuat anak-anak tidak sehat (Goode, 1994:204)

Pada umumnya, kita sering mendengar dogma yang dipakai oleh masyarakat bahwa "ibu tiri kejam". Konsep "ibu tiri kejam" sudah dikonstruksi sejak dahulu baik melalui lisan maupun perkembangan media. Namun, kita jarang mendengar "ayah tiri kejam" apalagi pada daerah yang menganut sistem kekerabatan matrilineal khususnya Minangkabau. Konsep kejam atau tidaknya juga berhubungan dengan bagaimana interaksi yang berjalan antara anak dengan ayah tiri dalam sebuah keluarga remarriage.

Pemberian interpretasi atas ayah tiri sebagai bagian baru di hidup anak dilalui melalui pola interaksi. Pola interaksi anak dengan ayah tiri diantaranya terkait dengan aktivitas keluarga remarriage, konteks sosial interaksi, aktor yang terlibat dalam interaksi, dan lain sebagainya. Apalagi ini dialami oleh anak yang sudah memasuki usia remaja. Mereka sebagai pihak yang paling rentan terhadap perubahan dalam keluarga berkemampuan untuk mengkonstruksi orang lain sesuai dengan pengetahuan yang tersimpan di dalam pikirannya yang diekspresikan melalui interaksi. Interaksi yang terjadi menghasilkan pemaknaan anak terhadap ayah tirinya.

Seharusnya kita harus memperhatikan pola interaksi anak dengan ayah tiri yang diharapkan mampu memahami pemaknaan anak terhadap ayah tirinya. Hal ini disebabkan seringnya mengabaikan apa yang dipikirkan anak dalam sebuah permasalahan maupun solusi dari permasalahan yang menimpa sebuah keluarga, apalagi keluarga remarriage. Terkadang, masalah yang timbul dalam keluarga dalam mengatasinya hanya terfokus kepada cakupan yang lebih besar seperti fungsi dari sebuah keluarga ataupun struktur keluarga itu sendiri tanpa menyelidiki lebih lanjut secara mendalam. Banyak sekali kriminalitas terkait dengan hal ini yang masih tidak kunjung selesai didalam proses penyelesaiannya diakibatkan keluarga remarriage itu sendiri yang gagal. Menurut analisa perspektif interaksionis, keluarga remarriage juga penting melihat permasalahan ayah tiri dari sisi anak sendiri. Berdasarkan uraian diatas maka permasalahan yang diangkat adalah : Bagaimana pola interaksi anak dengan ayah tiri dalam keluarga remarriage? 


\section{B. METODE PENELITIAN}

Penelitian ini menggunakan pendekatan kualitatif. Menurut Afrizal, (2014:13) pendekatan kualitatif merupakan metode penelitian ilmu-ilmu sosial yang mengumpulkan data berupa kata-kata (lisan maupun tulisan) dan perbuatan manusia serta peneliti tidak berusaha menghitung atau mengkuantifikasikan data kualitatif ke dalam bentuk angka-angka. Untuk tipe penelitian yang dipakai dalam penelitian ini adalah tipe penelitian deskriptif. Informan didapatkan dengan menggunakan digunakan teknik purposive sampling, yakni dengan cara mencari informan-informan yang sesuai dengan kriteria yang telah ditetapkan.

Informan dalam penelitian ini adalah anak, ayah tiri, dan ibu dalam keluarga remarriage. Data yang digunakan dalam penelitian ini adalah data primer yakni yang didapat peneliti langsung di lapangan serta data sekunder seperti data jumlah penduduk, luas daerah Kelurahan Kapalo Koto, Peta Kelurahan, jumlah penduduk usia anak 13-18, dan data jumlah keluarga remarriage di Kecamatan Pauh Kota Padang. Teknik pengumpulan data menggunakan observasi dan wawancara mendalam (indepth interview). Unit Analisis dalam penelitian ini adalah individu, yaitu anak. Dalam menentukan unit analisisnya berhubungan dengan penelitian ini sendiri menggunakan teori interaksionisme simbolik yang memang lebih terfokus kepada inter-subjektif. Penelitian ini berlokasi di Kelurahan Kapalo Koto Kecamatan Pauh. Lokasi dipilih sangat cocok dengan kasus remarriage terbanyak yang terjadi di Kecamatan Pauh Padang.

\section{STUDI PUSTAKA}

Pada penelitian ini yang mendeskripsikan interaksi anak dengan ayah tiri dalam keluarga remarriage, peneliti menggunakan paradigma definisi sosial. Definisi sosial erat kaitannya dengan Max Weber. Menurutnya sosiologi sebagai suatu studi tentang tindakan sosial antar hubungan sosial. Tindakan sosial adalah tindakan individu sepanjang tindakannya itu mempunyai makna atau arti subjektif bagi dirinya dan diarahkan kepada tindakan orang lain. Secara definitif, Weber mengartikan sosiologi sebagai ilmu yang berusaha untuk menafisirkan dan memahami tindakan sosial serta antar hubungan sosial (Ritzer, 2002:38).

Penelitian ini mencoba menganalisis permasalahan interaksi anak dengan ayah tiri dengan menggunakan teori interaksionisme simbolik dari Herbert Blumer. Menurut Blumer, makna yang dipunyai sesuatu tersebut berasal atau muncul dari interaksi sosial antara seseorang dengan sesamanya. Makna yang diperlakukan atau diubah melalui suatu proses penafsiran (interpretative process) yang digunakan orang dalam menghadapi sesuatu yang dijumpainya. Makna yang muncul dari interaksi tersebut tidak begitu saja diterima oleh seseorang melainkan ditafsirkan terlebih dahulu (Soenarto, 2004: 36).

Kekhasannya bahwa manusia saling menerjemahkan, mendefinisikan tindakannya, bukan hanya reaksi dari tindakan seseorang terhadap orang lain. Tanggapan seseorang tidak dibuat secara langsung atas tindakan itu, tetapi didasarkan atas makna yang diberikan. Olehnya, interaksi dijembatani oleh penggunaan simbol, penafsiran, dan penemuan makna tindakan orang lain. Dalam konteks ini, menurut Blumer, aktor akan memilih, memeriksa, berpikir, mengelompokkan, mentransformasikan makna sesuai situasi, dan kecenderungan 
tindakannya. Pada bagian lain, Blumer mengatakan bahwa individu bukan dikelilingi oleh lingkungan objek-objek potensial yang mempermainkan dan membentuk perilakunya, sebaliknya ia membentuk objek. Dengan begitu, manusia merupakan aktor yang sadar dan reflektif, yang menyatukan objek yang diketahuinya melalui apa yang disebutnya sebagai self-indication. Maksudnya, proses komunikasi yang sedang berjalan dimana individu mengetahui sesuatu, menilainya, memberi makna dan memberi tindakan dalam konteks sosial. Menurutnya dalam teori interaksi simbolik mempelajari suatu masyarakat disebut "tindakan bersama" (Ahmadi, 2005: 310).

Secara ringkas menurut Sobur (2004: 199), teori interaksionisme simbolik didasarkan pada premis berikut :

a. Individu merespon suatu situasi simbolik, mereka merespon lingkungan termasuk objek fisik (benda) dan objek sosial (perilaku manusia) berdasarkan media yang dikandung komponen lingkungan tersebut bagi mereka.

b. Makna adalah produk dari interaksi sosial, karena itu makna tidak melihat pada objek, melainkan dinegosiasikan melalui penggunaan bahasa, negosiasi itu dimungkinkan karena manusia mampu mewarnai segala sesuatu bukan hanya objek fisik, tindakan atau peristiwa (bahkan tanpa kehadiran objek fisik, tindakan atau peristiwa itu) namun juga gagasan yang abstrak.

c. Makna yang diinterpretasikan individu dapat berubah dari waktu ke waktu, sejalan dengan perubahan situasi yang ditemukan dalam interaksi sosial, perubahan interpretasi dimungkinkan karena individu dapat melakukan proses mental, yakni berkomunikasi dengan dirinya sendiri.

Selain penguatan dari teori Blumer, penelitian ini juga diperkuat menggunakan landasan perspektif sosiologi anak dan remaja. Menurut perspektif sosiologi anak dan remaja, anak dipandang sebagai subjek yang aktif dan subyektif. Tentulah penting rasanya ini menjadi kesadaran bahwa penting membahas masalah anak memakai perspektif dari anak itu sendiri. Hal ini senada dengan pandangan interaksionis bahwasanya manusia adalah makhluk yang kreatif.

Dari penjelasan diatas, hubungan antara anak dengan ayah tiri cocok jika dianalisis menggunakan teori interaksionisme simbolik. Hubungan anak dengan ayah tiri merupakan hubungan yang bisa dikaji dalam pemahaman subyektif. Proses sosial yang menyebabkan terjadinya interaksi antara anak dengan ayah tiri merupakan suatu tindakan yang benar-benar diarahkan kepada individu lain sesuai dengan tindakan yang dilakukan oleh individu tersebut yang didalamnya memiliki makna (meaning) dalam sebuah interaksi yang terjadi. Interaksi sosial yang dilihat tidak hanya berupa kata-kata, namun simbol bahasa, gerak-gerik dan respon anak terhadap interaksinya dengan ayah tiri juga akan diamati secara cermat. Kajian penelitian ini menggunakan teori interaksionisme simbolik akan menjawab persoalan anak dengan ayah tiri berikut dengan makna yang diberikan anak dalam sebuah interaksi yang dihasilkan tersebut, dan ini menjadi salah satu pilihan yang tepat dibandingkan pilihan teori yang lain.

\section{TEMUAN DAN PEMBAHASAN}

\section{Setting Interaksi Sosial}

Berdasarkan wawancara yang telah dilakukan, setting interaksi sosial menjadi salah satu faktor yang dapat menentukan hubungan anak dengan ayah tiri. 
Disediakannya ruang bagi keluarga untuk sekedar berbincang membuat anak mendapat hak atas afeksi dari orangtua. Hasil penelitian menunjukkan adanya beberapa setting interaksi anak yang terjadi dalam remarriage yang mampu membangun bonding dengan ayah tiri.

Pertama, makan malam Bersama. Makan malam dilakukan sebelum menunaikan shalat isya, sekitar jam 19.45 WIB. Waktu ini menjadi favorit karena inilah waktu senggang yang dimiliki oleh setiap anggota keluarga baik untuk memenuhi kegiatan produktif, sekolah, maupun kegiatan domestik. Terdapat perbedaan pola makan malam antara satu keluarga dengan keluarga yang lain tergantung kepada latar belakang keluarga. Kategori keluarga yang berasal dari keluarga pegawai negeri sipil (PNS) yakni ibu dan ayah tirinya bekerja hingga sore, makan malam disediakan setelah pulang dari beraktivitas seharian bekerja. Makan malam dilakukan setelah sholat magrib dan rutin setiap hari terpola seperti itu karena memang hanya saat-saat itulah ibu bisa memasak disebabkan oleh keterbatasan waktu yang dimiliki ibu dalam menjalankan tugas domestik sebagai ibu rumah tangga. Setelah makanan selesai dimasak, ibu menghidangkan makanan di meja makan. Namun, anak lebih memilih makan di depan tv sambil menonton tv. Terkadang ayah juga ikut makan di depan TV seperti anak walau tidak terlalu sering. Pada saat itulah terjadi interaksi antara anak dengan ayah tiri.

Kedua, mendampingi anak belajar. Ayah tiri juga ikut serta berkontribusi mendampingi anak dalam mengerjakan PR walau tidak semua ayah tiri yang melakukan hal yang demikian. Ayah tiri yang memiliki jenjang pendidikan formal yakni lulusan minimal SMA dan S1 yang mampu untuk menjalankan fungsi ini. Untuk belajar sendiri, anak biasanya meminta bantuan kepada ayah tiri jika ayah tidak dalam keadaan sibuk. Hal ini terjadi jika anak tidak mengerti dengan tugas sekolah yang diberikan oleh gurunya.

Metode yang diberikan oleh ayah tiri adalah dengan menjelaskan hal yang belum dipahami anak, lalu diberikan contoh soal. Kemudian, anak akan memperhatikan penjelasan dari ayah tiri, lalu anak akan mengerjakan soal yang diberikan.

Ketiga, menonton TV Bersama.Terdapat perbedaan pola menonton TV pada masing-masing keluarga. Untuk keluarga yang memiliki aktivitas sehari-hari yang rutin untuk melakukan kegiatan produksi, TV kerap kali diletakkan pada posisi yang lebih mudah untuk diakses supaya lebih mudah dijangkau jika ingin menonton TV bersama. Pada keluarga tipe seperti ini, anak ikut serta membantu ayah tiri dan ibu dalam melakukan kegiatan produktif, misalnya keluarga yang memproduksi mpek-mpek. Hal ini membuat interaksi terjalin secara langsung maupun tidak langsung. Ruang gerak yang kecil dalam sebuah rumah juga membuat anak dengan ayah tirinya bisa berinteraksi selalu setiap saat. Interaksi antara anak dengan ayah tiri bisa terjadi juga disebabkan karena jumlah TV yang hanya satu di rumah tersebut dan tidak adanya remote control membuat mau tidak mau saling terjadi komunikasi antar anggota keluarga. Ayah tiri meminta bantuan kepada anak untuk mengganti siaran, memperbesar atau memperkecil volume TV, dan lain sebagainya.

Persamaan hobi dan minat antara anak dan ayah tiri juga terlihat pada setting interaksi ini. Anak laki-laki akan lebih mudah dekat dengan ayah tirinya jika anak bersifat terbuka serta punya tayangan saluran TV yang sama. Walaupun terkadang 
faktor intervensi dari ayah kandung menjadi penghambat jika status ayah kandung adalah cerai hidup dengan ibunya. Kesamaan hobi juga mempengaruhi interaksi. Jika anak tertarik dengan saluran TV yang dipilih, perbincangan menjadi hangat sebagai bentuk interaksi. Anak laki-laki lebih mudah dekat dan tidak terlalu canggung jika dibanding dengan anak perempuan, apalagi pada usia pertumbuhan anak menuju dewasa awal.

Keempat, antar-jemput Anak ke Sekolah. Ayah tiri yang mengantar jemput anak disebabkan karena jarak rumah ke sekolah yang relatif jauh dan kesulitan jika menggunakan kendaraan bermotor, baik kesulitan pada biaya dan efektivitas waktu. Antar jemput dilakukan setiap hari. Anak diantar pada pukul 07.00 pagi lalu dijemput pada pukul 2 siang. Ayah tiri yang mengantarkan anak ke sekolah juga sekaligus untuk berangkat ke tempat bekerja yakni sebagai buruh harian lepas. Sedangkan pada waktu anak pulang sekolah, ayah tiri menjemput anak kemudian mengantarkan pulang ke rumah, lalu lanjut bekerja. Anak yang diantarkan adalah anak berusia SMA dan berjenis kelamin laki-laki.

Durasi interaksi yang berlangsung lama akan melahirkan intimacy secara alamiah, seperti rutinitas antar-jemput sekolah. Namun, tidak semua anak mau diantar jemput, begitupun dengan waktu yang dimiliki oleh ayah. Anak yang dijemput biasanya memiliki beberapa faktor seperti akses rumah yang kurang memadai, jarak rumah dan sekolah yang terlalu jauh, waktu luang ayah yang cukup, dan anak yang tidak memiliki fasilitas kendaraan bermotor. Terdapat perbedaan diantara keluarga ekonomi yang berkecukupan dan ekonomi menengah ke bawah. Hal ini disebabkan karena keluarga ini telah menyediakan fasilitas. Ayah tiri juga sibuk dengan karirnya sehingga tidak memiliki waktu yang cukup untuk interaksi saat anak akan bersekolah.

Kelima, rekreasi. Rekreasi yang dilakukan oleh ayah tiri tidak berlangsung dalam jangka panjang. Anak diajak untuk rekreasi hanya pada saat masih kecil. Ditambah lagi pada saat itu anak masih belum memiliki adik. Alasan sudah tidak intens rekreasi keluarga juga disebabkan oleh kurangnya alat transportasi untuk bisa menampung seluruh anggota keluarga. Namun, jika hari raya besar seperti Idul Fitri datang, anak tetap akan diusahakan untuk diajak rekreasi oleh keluarga. Alat transportasi yang digunakan adalah sepeda motor jika jarak dekat. Namun jika direncanakan, keluarga akan menyewa mobil rental jika melakukan perjalanan jauh. Rute perjalanan untuk jarak dekat biasanya seperti; RTH Imam Bonjol, Mall, pantai, dan sekitar tempat rekreasi dalam kota saja.

Keenam, saling mengunjungi keluarga. Tidak hanya untuk sekedar mengunjungi, namun disana ada banyak interaksi yang akan terjalin antara anak dengan ayah tiri serta keluarga dari ayah tirinya. Anak akan mengetahui bagaimana latar belakang ayah tiri, profil ayah tiri, dan kepribadiannya dari keluarganya. Kunjungan ke keluarga ayah tiri juga memberikan dampak besar bagaimana anak memeriksa latar belakang ayah tirinya untuk mencoba menginterpretasi berdasarkan perbandingan dasar ayah kandung dan ayah tiri didalam pengetahuan anak.

Berdasarkan penjelasan di atas, kita bisa menginterpretasikan bahwa ada berbagai macam pola yang bisa dilakukan anak dalam berinteraksi dengan ayah tiri. Pola tersebut tidak hanya dijalani di dalam rumah, tapi juga perlunya bonding anak terhadap keluarga remarriage di luar rumah seperti rekreasi dan saling 
mengunjungi keluarga untuk memperdalam makna figur ayah secara alamiah dalam diri anak.

\section{Konteks Interaksi Sosial}

Ada beberapa konteks yang membuat terjalinnya hubungan anak dengan ayah tirinya pada sebuah keluarga remarriage. Pertama, diberikan nasihat kepada anak. Untuk keluarga yang memiliki ekonomi yang baik, reward yang diberikan cenderung lebih ke arah materi daripada non materi. Reward yang didapat anak diantaranya adalah hadiah berupa uang jajan tambahan dan membelikan sesuatu yang diinginkan anak. Sedangkan untuk keluarga ekonominya yang kurang baik, reward yang diberikan adalah berupa pujian dan materi juga namun tidak semewah profesional. Namun, pemberian reward tersebut ternyata juga dipengaruhi oleh status ayah tiri. Jika ayah tiri memiliki anak dan cerai mati dengan anak, ayah tiri tidak terlalu memperhatikan reward untuk anak. Hal tersebut disebabkan oleh tidak inginnya ada rasa kecemburuan anak kandung atas kasih sayang yang berlebih kepada anak tirinya. Hal itu terjadi jika ayah berhubungan baik dengan anak kandung. Sedangkan untuk ayah tiri yang cerai hidup dan tidak berkomunikasi dengan anak memberikan reward, namun tergantung dengan seberapa dekat ia dengan anak. Untuk memberikan reward sendiri, lebih banyak ibu yang meminta ayah tiri sebagai inisiator dalam memberikan reward tersebut.

Kedua, pamit sebelum bepergian. Hal ini melambangkan diberikannya perhatian kepada anak ketika hendak pergi ke suatu tempat, sedangkan untuk orang memberikan perhatian melambangkan bahwa anak dianggap penting bagi ayah tiri. Anggapan seperti itulah yang kemudian membuat ranah ini menjadi interaksi sebagai tujuan dalam sebuah hubungan. Ketiga, Mengarahkan Pendidikan Anak. Ayah tiri juga menanyakan mengenai kemana anak akan melanjutkan sekolahnya, hobi anak, dan keinginan anak untuk masa depannya.. Keluarga yang memiliki ekonomi yang mencukupi mengarahkan anaknya dengan beraneka ragam orientasi diantaranya yakni sekolah, minat atau hobi, dan keinginan anak. Ayah tiri juga terkadang menanyakan tentang hal-hal yang sudah dipersiapkan anak untuk mencapai cita-citanya.

\section{Keterlibatan Ibu dalam Interaksi Anak Dengan Ayah Tiri}

Dalam proses interaksi anak dengan ayah tiri, ada kalanya interaksi tersebut tidak berjalan sebagaimana mestinya yang diharapkan. Tidak semua interaksi berjalan dengan lancar. Apalagi, jika yang akan berinteraksi adalah dua orang asing yang kemudian dipersatukan dalam sebuah keluarga baru. Interaksi tersebut membutuhkan setidaknya inisiator dari interaksi untuk memulai dikarenakan masih timbulnya perasaan canggung dan tidak terbiasa baik dari anak maupun ayah tiri.

Ayah tiri cenderung terlihat dominan menjadi inisiator dari interaksi atas permintaan dari ibu. Ayah tiri memulai sejak awal pernikahan hingga anak benarbenar bisa belajar menjadi inisiator interaksi juga sehingga tercipta hubungan timbal balik yang sesungguhnya. Namun, butuh beberapa bantuan yang diberikan oleh ibu dalam upaya anak menjadi inisiator juga dalam interaksi tersebut. Dalam upaya menjadikan anak sebagai interaksi, peran ibu juga dominan di dalamnya. Penyampaian pesan atau perhatian dari ayah tiri ke anak melalui ibu menjadi 
gerbang besar anak bisa memahami bahwa anak dianggap penting di dalam pikiran ayah tiri sendiri. Ibu sebagai aktor terlibat terkadang bertindak sebagai aktor bukan semata-mata diminta oleh ayah tiri maupun anak, namun dilakukan secara sukarela agar membantu menciptakan suasana yang nyaman dan harmonis dalam sebuah keluarga remarriage.

\section{Self-Indication Anak Berinteraksi dengan Ayah Tiri}

Interpretasi anak terhadap ayah tirinya lebih banyak tersimpan dalam pikiran anak daripada diceritakan kepada aktor yang terlibat dengan keluarga remarriage khususnya ibu. Ada yang diceritakan, tapi tidak seberapa. Hal ini disebabkan karena banyak anak yang merestui pernikahan remarriage ibu mereka lantaran tidak ingin ibu kesepian pasca cerai dengan ayah, baik hidup maupun mati. Ada beberapa kecenderungan yang terjadi dalam penilaian anak terhadap ayah tiri. Kecenderungan tersebut tergantung kepada status perceraian orangtuanya. Jika orangtuanya mengalami cerai hidup, anak akan mudah dalam melakukan penyesuaian dengan ayah tiri dan merespon balik terhadap penyesuaian ayah tiri kepada anak. Hal ini disebabkan karena ditinggalkannya anak secara sengaja walau dengan alasan apapun akan selalu berpengaruh kepada interpretasi anak terhadap ayah kandungnya. Apalagi jika harus meminta anak untuk tetap menghormati dan mendoakan ayah kandungnya. Penilaian anak terhadap ayah kandungnya akan baik-baik saja jika ayah kandung tetap menjaga hubungan yang baik dengan anak, seperti menanyakan kabar anak, memberi perhatian, serta memberikan nafkah anak. Namun sebaliknya, jika anak ditinggalkan karena ayah telah meninggal dunia, anak akan lebih sulit menilai baik dan objektif kepada ayah tiri. Apalagi jika didukung oleh kenyataan bahwa ayah tiri kurang terbuka dan kurang melakukan pendekatan yang baik dengan anak. Anak yang memiliki ayah tiri yang telah meninggal agak keras dan bersikukuh bahwa bagaimanapun, tidak akan sama rasa kasih sayang antara ayah kandung dengan ayah tiri walau ia juga menyajikannya dengan cara yang sama. Ada kecanggungan yang dialami anak sehingga ia takut salah dan tidak bisa bertindak secara leluasa.

\section{Ayah Tiri sebagai Pelengkap Keluarga}

Anak memiliki self-indication dalam memaknai keberadaan ayah tiri dalam keluarga barunya. Perbedaan pemaknaan oleh anak tergantung kepada seberapa intim bonding yang diberikan ayah tiri kepada anak sambungnya. Ada dua selfindication yang dimaknai oleh anak yakni ayah tiri sebagai pelengkap keluarga atau sebagai figure pengganti. Bagi anak, yang memaknai ayah tiri sebagai pelengkap dalam sebuah keluarga remarriage, Ayah tiri akan tetap menjadi ayah bagi kehidupannya untuk memainkan peran ayah kandungnya. Anak yang mengindikasikan diri untuk memaknai ayah yang seperti ini umumnya terjadi kepada anak yang cerai hidup dengan ayah kandungnya dan tidak berhubungan baik dengan ayah kandungnya.

Anak yang mengalami cerai hidup dan hubungan yang tidak baik dengan anak akan menghasilkan anak yang tidak menghormati ayah kandungnya dan ia akan menganggap ayah tiri mampu dalam melengkapi keluarganya yang telah pernah pecah. Pemaknaan anak terhadap ayah tiri yang seperti ini dianggap sebagai level terbaik anak dalam memaknai ayah tiri secara positif. Hal ini disebabkan 
karena anak menerima dengan senang hati keberadaan ayah tiri di rumahnya. Penganggapan bahwa ayah tiri tidaklah sedarah memang masih melekat di hati anak, namun semuanya bisa tertutupi dengan sikap dan perilaku baik dari ayah tiri itu sendiri.

Pengalaman menjadi faktor penentu bagaimana ayah tiri bersikap kepada seorang anak. Apalagi berbicara tentang konsep adil, ayah tiri yang memiliki pengalaman menjadi anak tiri akan memakai metode pengenalan anak kandung dan anak tiri secara baik, contohnya adalah dengan menjadikan anak sebagai media pemberian uang jajan kepada anak kandung ayah tirinya (saudara tiri anak). Hal ini dilakukan oleh ayah tiri untuk melakukan transparansi atas uang saku kepada anak tiri maupun anak kandung tanpa ada pembeda sama sekali.

Anak yang memahami ayah tiri sebagai pelengkap dengan keluarga akan bersedia untuk mencari tahu atau memeriksa latar belakang ayah baik secara langsung maupun tidak langsung. Secara langsung yang dilakukan oleh anak adalah dengan menanyakan sendiri atau diberitahu langsung oleh ayah tirinya terkait dengan jumlah anak, umur, makanan kesukaan, perkenalan dengan ibu sebelumnya, dan lain sebagaimana. Hal tersebut menjadi bukti keinginan anak untuk mengenal baik sosok ayah tirinya.

\section{Ayah Tiri sebagai Figur Pengganti}

Sedangkan anak memahami ayah tirinya sebagai figur pengganti dalam sebuah keluarga adalah anak merasa bahwa tidak mudah baginya untuk menganggap ayah tiri menjadi bagian dari keluarganya, namun anak juga tetap menerima keberadaan ayah tirinya. Ini adalah bagian transisi anak menuju ayah sebagai pelengkap sebuah keluarga. Indikasi diri anak dalam memaknai ayah tiri seperti yang telah disebutkan diatas dipengaruhi oleh beberapa faktor. Kecenderungannya adalah anak yang berstatus cerai mati dengan ayah kandungnya dan anak yang cerai hidup namun masih berhubungan baik dengan ayah kandungnya. Faktor cerai mati tidak disebabkan oleh ditinggalkannya anak secara sengaja, melainkan karena sudah ketetapan Tuhan, anak cenderung menerima ada figur pengganti dalam keluarganya, namun tetap saja posisi ayah kandung tidak bisa digantikan oleh ayah tiri yang ada di keluarganya sekarang. Anak tetap merasa memiliki ayah kandung di tengah kehidupan keluarganya secara tidak nyata, namun ayah tiri tetap menjadi pengganti pada bagian kenyataannya.

Untuk anak yang cerai hidup namun memiliki hubungan yang baik dengan ayah kandungnya, disebabkan karena tidak merasa hilangnya ayah kandung di dalam diri anak, karena posisi ayah kandung masih ada untuk anak dan berada di sekitar kehidupan anak. Penjelasan lainnya adalah dikarenakan adanya intervensi dari ayah kandung untuk mempengaruhi anak dalam berhubungan dengan ayah tirinya, mulai dari stereotip, dugaan sementara, dan kontribusi ayah kandung dalam memaksa anak menilai buruk ayah tiri.

Anak yang memaknai ayah tirinya sebagai figure pengganti adalah seorang anak yang masih canggung, tidak leluasa, dan takut salah bicara dengan ayah tirinya. Hal ini berhubungan juga dengan anak yang melakukan perbandingan dengan ayah kandung dan ayah tirinya. Jika ada beberapa sikap yang tidak dimiliki oleh ayah tirinya sekarang, anak akan merasa ada yang kurang dan tidak begitu leluasa dengan ayah tirinya. 


\section{E. KESIMPULAN}

Setting interaksi sosial anak dengan ayah tiri adalah makan malam bersama, didampinginya anak belajar, menonton TV bersama, antar jemput anak ke sekolah, rekreasi, dan mengunjungi keluarga ayah tiri. Konteks interaksi sosial anak dengan ayah tiri terbagi menjadi dua yaitu interaksi sebagai alat komunikasi dan interaksi sebagai tujuan komunikasi, dan keterlibatan ibu dalam interaksi anak dengan ayah tiri. Interaksi sebagai alat komunikasi adalah pemberian nasihat dan memberikan reward kepada anak. Selanjutnya interaksi sebagai tujuan komunikasi adalah pamit dan bersalaman sebelum bepergian dan mengarahkan orientasi anak ke depan. Adapun keterlibatan ibu dalam interaksi anak dengan ayah tiri adalah aktifnya peran ibu sebagai inisiator dalam interaksi anak dengan ayah tiri. Self indication anak dalam berinteraksi dengan ayah tiri adalah ayah tiri dimaknai sebagai pelengkap sebuah keluarga dan ayah tiri dimaknai hanya sebagai figur pengganti dalam sebuah keluarga.

\section{F. UCAPAN TERIMAKASI}

Penulis mengucapkan terima kasih kepada pembimbing yang telah memberikan dukungan akademik dan non akademik dalam jalannya penelitian. Penulis juga mengucapkan terima kasih kepada semua informan yang telah mengalokasikan waktunya untuk memberikan data yang berkaitan dengan penelitian. Penulis juga mengucapkan terima kasih kepada semua pihak yang ikut terlibat serta tidak bisa disebutkan satu per satu.

\section{DAFTAR PUSTAKA}

\section{Afrizal. 2014. Metode Penelitian Kualitatif: Sebuah Upaya Mendukung Penggunaan}

Penelitian Kualitatif Dalam Berbagai Disiplin Ilmu. Jakarta : PT Raja Grafindo

Persada.

Badan Pusat Statistik. 2017. Kecamatan Pauh dalam Angka. Padang: BPS Kota Padang. Bungin, Burhan. Sosiologi Komunikasi. Jakarta: Kencana.

Damsar. 2015. Pengantar Teori Sosiologi. Jakarta: Kencana. 2012. Pengantar Sosiologi Pendidikan. Jakarta: Kencana.

Goode. William. 2007. Sosiologi Keluarga. Jakarta: Bumi Aksara.

Horton, B. Paul and Chester L Hunt. 1996. Pengantar Sosiologi. Jakarta: Erlangga.

Kartono, Kartini. 2010 Patologi Sosial 3. Jakarta: Raja Grafindo Persada.

2013. Patologi Sosial 2. Jakarta: Raja Grafindo Persada.

Moleong, Lexy J. 2004. Metodologi Penelitian Kualitatif Edisi Revisi. Penerbit Rosda.

Ramayulis. 1990. Pendidikan Islam dalam Rumah Tangga. Jakarta: Kalam Mulia Statistik.

Ritzer, George \& Douglas J Goodman. 2004. Teori Sosiologi Modern. Jakarta: Prenada Media.

Ritzer, George. 2013. Sosiologi Berparadigma Ganda. Jakarta: Rajawali Press.

Schaefer. Richard T. 2012. Sosiologi. Jakarta : Salemba Humanika.

Sobur. Alex. 2004. Semiotika Komunikasi. Bandung: Remaja Rosdakarya.

Sugiyono. 2010. Metode Penelitian Kuantitatif Kualitatif dan RED. Bandung: Alfabeta.

Suyanto, Bagong. 2010. Masalah Sosial Anak. Jakarta: Kencana Prenada Media Group. 


\section{Skripsi :}

Agnes, Yurika. 2010. "Pencapaian Identitas Diri pada Remaja yang Memiliki Ibu Tiri". Jakarta: Skripsi Jurusan Psikologi Universitas Gunadarma.

Fajarwati, Indah. 2010. "Pertumbuhan Pasar Baru Kecamatan Pauh Kota Padang". Padang: Skripsi Jurusan Ilmu Sejarah Universitas Andalas.

Mufidatul, Fatihul. 2015. "Penerimaan Diri Remaja terhadap Keluarga Tiri".Malang:Skripsi Jurusan Psikologi Fakultas Psikologi Universitas Islam Neger Maulana Malik Ibrahim.

Rossanda, Titis. 2011. “Komunikasi Adaptasi Keluarga Dalam Remarriage". Semarang: Skripsi Jurusan Ilmu Komunikasi FISIP Universitas Diponegoro.

\section{Artikel Jurnal :}

Sidik, Stanislaus. 2014. "Strategi Manajemen Konflik Komunikasi Intrapersonal antara Ibu dengan Anak Tiri". Jurnal E-Komunikasi Vol. 2 No. 3 Jurusan Ilmu Komunikasi Universitas Kristen Petra Surabaya.

Warshak, 2010. "Remarriage As A Trigger of Parental Alienation Syndrome".Vol. 18 No.5 Tahun 2010 The American Journal of Family Therapy. 